\title{
PENGARUH FLUKTUASI INDUSTRIALISASI TERHADAP KAPABILITAS MASYARAKAT PEDESAAN DI MAGELANG: PERSPEKTIF PERENCANAAN WILAYAH
}

\section{THE EFFECT OF INDUSTRIALIZATION FLUCTUATION ON RURAL COMMUNITY CAPABILITY IN MAGELANG: A REGIONAL PLANNING PERSPECTIVE}

\author{
R. Widodo Dwi Pramono ${ }^{a}$ \\ a'Departemen Teknik Arsitektur dan Perencanaan Fakultas Teknik Universitas Gadjah Mada, Yogyakarta; pramono_wid@ugm.ac.id \\ Info Artikel: \\ - Artikel Masuk: 19/04/18 \\ - Artikel diterima: 25/05/18 \\ - Tersedia Online: $24 / 08 / 18$
}

\begin{abstract}
ABSTRAK
Industrialisasi sebagai pemicu transformasi struktur ekonomi, sangat penting bagi proses perkembangan wilayah. Namun, industrialisasi dapat mengalami fluktuasi. Wilayah yang bergantung pada investasi luar, sering mengalami deindustrialisasi akibat migrasi industri ke wilayah yang dianggap lebih menguntungkan, misalnya karena tenaga kerja yang lebih murah dan pasar yang sedang berkembang. Bagaimana akibat perkembangan industrialisasi dan de-industrialisasi pada masyarakat lokal yang agraris? Tulisan ini bertujuan untuk menjawab pertanyaan tersebut dari perspektif perencanaan wilayah. Dengan mengambil kasus pada 2 kecamatan di Magelang dan berdasarkan data series dari tahun 1970-an hingga 2010 serta observasi investigatif secara langsung ke masyarakat, penelitian mengungkap akibat positif dan negatif dari perkembangan industri di wilayah ini, dan sisi positif maupun negatif dari fase de-industrialisasi. Pada masa perkembangan industri, hal yang paling positif adalah meningkatnya rasio lahan per petani yang memberi peluang bagi unit usaha petani untuk meningkatkan skala ekonominya melalui sewa-menyewa lahan. Temuan lain yang menarik adalah de-industrialisasi Industri skala menengah dan besar yang investasinya dari luar, memicu re-industrialisasi oleh masyarakat lokal dalam bentuk pertumbuhan industri rumah tangga. Dari tulisan ini, dalam melakukan tugasnya, perencana wilayah harus mengantisipasi dinamika seperti arahan alokasi penggunaan lahan serta manajemen pemanfaatanya.

Kata Kunci: Perencanaan wilayah, Industrialialisasi, de-industrilasasi, re-industrialiasi, tanah pertanian, kapabilitas masyarakat
\end{abstract}

\footnotetext{
ABSTRACT

Industrialisation as a trigger of the economic structure transformation, is very important for regional development process. However, industrialisation can experience fluctuations. Areas that rely on outside investments, often encountered the deindustrialisation due to industrial migration to more profitable areas, for example cheaper labor and emerging markets. What is the result of the development of industrialization and de-industrialization in an agrarian local society? This paper aims to answer the question from the perspective of regional planning. By taking cases in two sub-districts in Magelang and based on data series from the 1970 s to 2010 and direct investigative observations to the community, the study revealed the positive and negative effects of industrial development, and the positive or negative side of the de-industrialization phase. At the time of industrial development, the most positive thing is the increase of the ratio of land per farmer who gives an opportunity for the farmer's business unit to rise the scale of its economy through the land renting. Another interesting finding is the de-industrialization of medium- and large-scale industries whose investment from outside, triggering reindustrialization by local communities into home based industry growth. From this paper, in performing its duties, regional planners should anticipate dynamics such as land use allocation and management.

Keyword: Regional Planning, Industrialization, De - Industrialization, Re - Industrialization, Agriculture Land, Community Capabilities

Copyright $\odot 2018$ JPWK-UNDIP This open access article is distributed under a Creative Commons Attribution (CC-BY-NC-SA) 4.0 International license.

Cara men-sitasi (APA 6th Style):

Pramono, R. Widodo Dwi (2018). Pengaruh Fluktuasi Industrialisasi Terhadap Kapabilitas Masyarakat Pedesaan di Magelang: Perspektif Perencanaan Wilayah. Jurnal Pembangunan Wilayah dan Kota, Vol 14 (2), $95-107$
} 


\section{PENDAHULUAN}

Perencanaan pembangunan wilayah merujuk pada praktik-praktik persiapan pembangunan pada luasan lahan wilayah tersebut. Perencanaan sendiri pada umumnya adalah upaya mengarahkan/mengelola perubahan sosial, ekonomi, dan fisik sebuah wilayah (Friedmann, 1996), dengan tujuan meningkatkan kesejahteraan masyarakat sehingga tidak tertinggal dari wilayah lain. Berdasar pengertian ini, perubahan struktur ekonomi sosial kependudukan terkait dengan pekerjaan, yang disebut sebagai transformasi struktural ekonomi, perlu dipahami oleh perencana wilayah untuk dikelola dan diwadahi dalam proses kegiatan sistematis seperti ketika mengajukan dan menganggarkan proyek-proyek infrastruktur, dan juga kegiatan kreatif seperti merancang desain-desain alternatif peruntukan lahan di masa mendatang. Pendekatan sistematis dan kreatif ini meliputi serangkaian proses pembangunan termasuk penyusunan rencana, penerapan, evaluasi kebijakan dan peraturan, serta program aksi. Kebijakan bisa meliputi fiskal, subsidi, tata guna lahan dan pertanahan, dan prioritas investasi (misalnya, Armstrong dan Taylor, 2000). Peraturan panduan pembangunan wilayah terdiri dari penetapan tujuan, kepemilikan, pendanaan, pembuatan perjanjian, norma-norma lingkungan, dan izin penggunaan tanah dan guna lahan (misalnya, Kim, 2011). Industrialisasi adalah salah satu proses yang memicu transformasi struktural ekonomi (Kaldor, 1966), perlu menjadi salah satu bidang kajian dan perhatian dalam disiplin perencanaan wilayah. Fluktuasi industrialisasi yang dimaksud dalam tulisan ini adalah proses dinamika industrialisasi yang di dalamnya juga mengalami yang disebut dengan de-industrialiasi dan re-industrialisasi. Industrialisasi sendiri merupakan merupakan proses perubahan struktur ekonomi dimana terdapat kenaikan kontribusi sektor industri dalam permintaan konsumen, PDB, ekspor dan kesempatan kerja yang menggeser dominasi sektor primer seperti pertambangan dan pertanian. Industrialisasi juga dapat dipahami sebagai proses modernisasi ekonomi yang bertujuan meningkatkan nilai tambah seluruh sektor ekonomi dengan sektor industri pengolahan dan perakitan/manufaktir sebagai leading sector (Arsyad, 2004). Selaras dengan hal ini, Kaldor (1966) serta Dasgupta dan Singh (2006) meyakini bahwa sektor manufaktur merupakan mesin pertumbuhan bagi suatu negara atau wilayah. Namun demikian, dalam fase tertentu ada fenomena dari penurunan dominasi industri yang disebut dengan de-industrialisasi.

De-industrialisasi telah menjadi area penelitian menarik sejak pertengahan abad 20 terutama di negara maju (Škuflić \& Družić, 2016). Škuflić \& Družić menggunakan definisi para peneliti sebelumnya (Rowthorn \& Ramaswamy, 1997; Sachs, Shatz, Deardorff, \& Hall, 1994) yang menyatakan de-industrialisasi sebagai fenomena penurunan absolut ataupun relatif dari tenaga kerja dan kontribusi dari PDRB sektor industri. Hal penting yang diargumentasikan oleh Škuflić \& Družić adalah bahwa de-industrialisasi tidak selalu berakibat negatif. Terutama ketika mengobservasi Eropa, mereka menyatakan bahwa deindustrialisasi adalah fenomena lebih lanjut dari transformasi ekonomi menuju dominasi sektor ke tiga dan ke empat yang bisa lebih produktif. Pendapat ini sejalan dengan pendapat Rowthorn dan Wells (1987) diacu dalam Rowthorn \& Ramaswamy (1997) yang berargumentasi bahwa terjadinya de-industrialisasi pada negara maju merupakan de-industrialisasi positif karena merupakan sebuah konsekuensi dari proses pembangunan pada sebuah sistem perekonomian yang telah maju, yang bertransformasi pada sektor tersier. Membandingkan argumentasi dari Rowthorn dan Wells (1987), de-industrialisasi di Indonesia pada kurun waktu 1983 - 2008 lebih bisa mengarah pada indikasi Kitson dan Michie (1997) yang menyebutkan bahwa de-industrialisasi bisa juga sebagai pertanda lemahnya perekonomian suatu wilayah. Untuk itu, muncullah perbincangan mengenai perlunya re-industraliasai di Indonesia. Re-industrailiasasi dapat dipahami sebagai upaya untuk mendongkrak kembali kekuatan industrailisasi sebagi pemicu pertumbuhan wilayah. Mirana (2008) berpendapat bahwa re-industrialisasi adalah upaya menempatkan kembali industri sebagai cara penting dalam memecahkan masalah ekonomi dan sosial. Artinya, upaya ini memposisikan sektor industri untuk berperan kembali dalam perekonomian seabagai proses peningkatan kesejahteraan masyarakat.

Bagaimana sebenarnya fluktuasi industrialisasi berpengaruh terhadap masyarakat pada suatu wilayah di Indonesia? Negatif atau positifkah? Tulisan ini bertujuan untuk menunjukkan menjawab pertanyan ini pada suatu kasus di suatu bagian wilayah. Pemikiran dasar yang dipakai untuk mencoba 
mengungkap fenomena ini secara seimbang adalah pendapat dari Browett (1985) dalam tulisannya berjudul "The Newly Industrializing Country and Radical Theories of Develompent" yang menyatakan bahwa kegagalan industri pada suatu fase tidak harus selalu dinilai negatif secara menyeluruh. Browett berargumentasi bahwa kegagalan neo Marxist dependency perspective dalam distribusi kapital masih memberi harapan dampak positif pada masyarakat dengen adanya social-reproduction yang dipicunya. Hal ini didukung oleh beberapa peneliti lain, yang berargumen bahwa industrialisasi, meskipun terjadi penurunan atau bahkan berhenti, dapat memberi transfer teknologi (Bloch 2000), membangunan institusi, maupun memperkuat social capability and economic growth (Putterman 2013). Penelitian ini mengkonfirmasi pendapat Browett (1985) bahwa meskipun berhentinya sebagian industri telah menjatuhkan kembali perekonomian masyarakat dalam waktu dekat, namun pada jangka agak panjang (menengah) industri, telah meninggalkan keterampilan yang menjadi modal bagi masyarakat lokal untuk bangkit kembali. Meskipun Kitson dan Michie (1997) menyebut bahwa de-industrialisasi juga sebagai pertanda lemahnya perekonomian suatu wilayah, kasus di wilayah penelitian lebih memberi relevansi pendapat Kaldor (1966) serta Dasgupta dan Singh (2006) yang meyakini bahwa sektor manufaktur dapat secara efektif menjadi mesin pertumbuhan bagi suatu negara atau wilayah, meskipun pola pertumbuhanya dapat terjadi naik dan turun. Yang sangat menarik dari kasus ini adalah fenomena re-industrialisasi yang dimotori oleh pelaku lokal setelah dapat menyerap keterampilan dari industri besar-menngah yang datang dari luar. Fenomena dalam penelitian ini mendukung pendapat Mirana (2008) bahwa re-industrialisasi merupakan salah satu cara penting dalam memecahkan masalah ekonomi dan sosial. Cara ini memposisikan sektor industri untuk mendorong kembali perannya dalam sektor perekonomian yang mampu meningkatkan kesejahteraan, bahkan akhirnya berbasis kekuatan masyarakat lokal itu sendiri.

Tulisan ini mengungkap fenomena dampak fluktuasli industrialisasi pada suatu wilayah yang pada dasarnya memiliki sifat pedesaan. Hasil penelitian ini menunjukkan bahwa industrilasi di wilayah ini telah melalui fase perkembangan, de-industrialiasasi, dan re-industrialisasi yang dalam tulisan ini disebut sebagai fenomena fluktuasi industrialisasi. Jika awal perkembangan dan de-industrialsiai dialami oleh industri besar dan menegah, re-industrialiasasi terjadi dalam bentuk perkembangan industri kecil rumah tangga. Modal utama re-industrialsiai adalah keterampilan yang ditinggalkan oleh industri besar dan menengah. Salah satu penelitian sejenis dilakukan di Cina oleh Sigurdson (1977) yang membuktikan bahwa rural industrialization di Cina memainkan peran penting terhadap proses transformasi sosial di masyarakat pedesaan. Terkait dengan transformasi di pedesaan akibat industrialisasi Alvares, et al (2011) menemukan salah satu perubahan yang terjadi berakiatan dengan distribusi lahan/tanah. Penelitian-penelitian tentang industriaslisasi dan transformasi struktural ekonomi biasanya dilakukan dalam skala makro dari perspektif aekonomi. Untuk mendukung cara kerja perencanaan wilayah, terutama yang berfokus pada perencanaan tata ruang, perlu dilakukan penelitaian pada skala yang lebih detail. Penelitian ini dilakukan pada kasus 1 (satu) wilayah kabupaten, berfokus pada 2 (dua) kecamatan dan pendalaman pada satu unit komunitas. Fokus transformasi pada masalah penguasaan tanah yang menjadi salah satu objek tugas perencanaan wilayah selain infrastruktur. Perspektif penelitian didasarkan pada pendekatan kapabilitas yang diyakini menjadi dasar kerangka evaluasi sebagai bagian dari proses perencanaan wilayah berbasis pada masyarakat (Pramono, 2011). Menginterpretasi konsepsi Sen (2000), Pramono (2011) mendefiniskan kapabilitas merupakan tingkat seseorang dalam melakukan atau menciptakan functioning berdasar derajat dukungan atau hambatan yang berasal dari tingkat ketersediaan dan keterjangkauan aset, termasuk aset berupa akses terhadap tanah. Functioning merupakan kegiatan yang dapat dilakukan oleh masyarakat, dalam penelitian ini misalnya untuk meningkatkan skala usaha ekonomi dalam rangka meningkatkan kesejahteraan. 


\section{DATA DAN METODE}

Penjelasan mengenai fenomena pengaruh fluktuasi perkembangan industri terhadap penguasaan tanah dan kapabilitas petani dalam tulisan ini dilandaskan pada observasi lapangan dan analisis data statistik. Fluktuasi indstrialiasai diobservasi berdasar data sekunder yang dikeluarkan oleh Badan Pusat Statistik berupa data seri jumlah industri dan tenaga kerja yang dikompilasi dari Kabupaten Magelang dalam Angka yang diterbitkan BPS antara tahun 1975-2005. Data penguasaan tanah diungkap dari pengolahan data sekunder sensus (BPS 2004) yang dikonfirmasi dengan wawancana dari narasumber pelaku. Sedangkan kapabilitas petani didapatkan dari wawancara mendalam, baik untuk konfirmasi penguasan tanah maupun menggali pengaruh hal tersebut terhadap kapabilitas masyarakat didasarkan pada wawancara mendalam terhadap 30 responden yang dipiih secara purposive dan snowbowling pada 2 kecamatan; 15 dari Kecamatan Borobudur, dan 15 dari Kecamatan Tempuran. Responden yang dipilih dimulai dari para tokoh yang dianggap mengerti sejarah perkembangan masyarakat dan pembangunan industri di wilayah tersebut, dan diminta untuk menunjukkan responden berikutnya untuk mendalami lebih lanjut isu yang muncul dari wawancana dengannya. Karena yang diteliti terkait dengan perubahan, para responden dipilih berasal dari berbagai tingkat usia untuk mampu memberikan evaluasi perbandingan yang berbeda berdasar histori. Variasi lokasi juga dilakukan untuk memberi menjamin representasi dari fenomena. Untuk memenuhi syarat ini, ditentukanlah rute spesifik secara mingguan. Pada umumnya wawancara dilakukan pada sore hari untuk responden tenaga kerja industri dan pada pagi hari di ladang pada responden petani. Survei persepsi untuk memahami perubahan kapabilitas dilakukan dengan mengajukan pertanyaan sederhana namun fundamental mengenai persepsi masyarakat terhadap kualitas hidup saat ini, serta peningkatan dan kemajuan yang mereka tangkap di sekitar mereka.

Hasil informasi dari wawancana mendalam dituliskan dalam bentuk narasi, kemudian dicatat katakata pentingnya (key words). Hasil ini diklasifikasikan untuk mendapatkan generalisasi pesepsi tentang perubahan-perubahan yang mereka alami serta evaluasi baik atau buruknya pengaruh terhadap kehidupan mereka atau masyarakat di sekitar mereka. Hasil generalisasi berdasarkan frekuensi kata kunci yang muncul, diinterpretasi secara kualitatif, dikaitkan dengan informasi yang berasal data-data statistik yang telah dikumpulkan sebelumnya untuk mendapatkan tema-tema temuan sebagaimana dipaparkan pada bagian hasil dan pembahasan.

\section{HASIL DAN PEMBAHASAN}

\section{1. Fluktuasi industrailisasi di Kabupaten Magelang}

Industrialisasi di Indonesia sejak masa Soeharto hingga saat ini, tidak dapat dipungkiri telah mengakibatkan transformasi struktural di Indonesia. Selama 30 tahun sebelum terjadinya krisis keuangan dan ekonomi pada tahun 1997/1998, sektor industri Indonesia mengalami transformasi dan pertumbuhan yang cepat. Bertrand dan Osborne (1959) mengungkap bahwa pembangunan pabrik-pabrik besar maupun kecil di Indonesia, khususnya di Jawa telah meningkatkan pendapatan daerah dan membuka lapangan kerja baru, sehingga kemudian dapat menurunkan angka pengangguran di pedesaan dan menciptakan kondisi sosial-ekonomi yang lebih baik dari sebelumnya.

Pembangunan industri dalam skala agak masif di Magelang dimulai tahun 1980-an. Akan tetapi, beberapa industri, kebanyakan tekstil dan karoseri, sudah beroperasi beberapa tahun sebelumnya (pertengahan 70-an) dan menyebar ke beberapa kecamatan. Gambar 1 menujukkan industri di Magelang yang mulai eksis dan tumbuh sejak 1975 hingga 1989 dan sempat menurun pada 1990, meningkat lagi pada periode 1994-1999 dan kemudian cenderung stagnan setelahnya. 


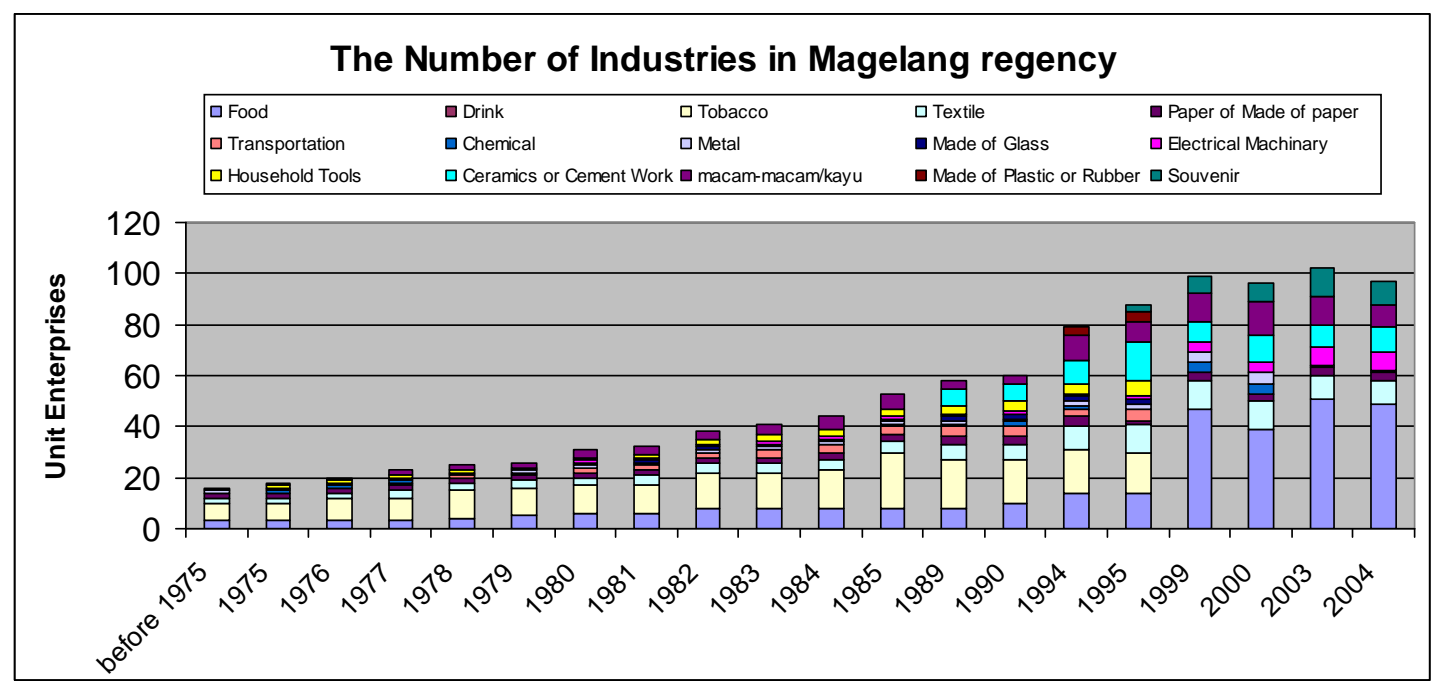

Gambar 1 Jumlah Industri di Magelang (disarikan dari Kabupaten Magelang dalam Angka, BPS 1975-2005)

Fluktuasi industrialisasi juga terlihat dari data perkembangan tenaga kerja. Sebagaimana ditunjukkan pada gambar 2, sejak tahun 1998 tenaga kerja industri terus meningkat. Penurunan terjadi selama krisis moneter pada tahun 1998 hingga 2000 kemudian meningkat lagi setelah periode tersebut.

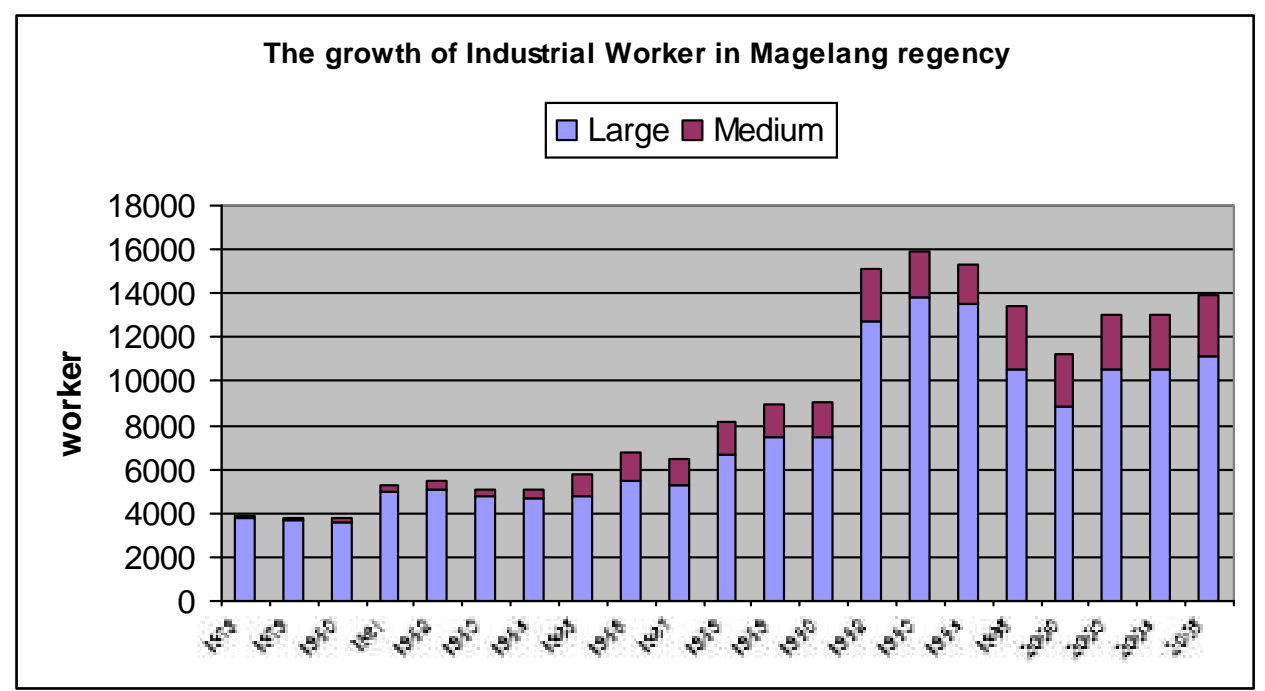

Gambar 2. Pertumbuhan Tenaga Kerja Industri di Kabupaten Magelang (disarikan dari Kabupaten Magelang dalam Angka, BPS 1975-2005)

\section{2. Nilai Tanah bagi Masyarakat Magelang}

Kepemilikan tanah diatur dalam UU No 5 tahun 1960 yang kemudian dikenal dengan Undang-Undang Agraria. Berdasar kepemilikanya, tanah terbagi mejadi tanah negara, tanah adat dan tanah milik. Di Magelang, hampir $100 \%$ lahan dimiliki oleh perseorangan. Konsekuensinya, alokasi tanah kebanyakan tergantung pada pertimbangan individu. Selain itu, tanah terdistribusi secara merata kepada beberapa orang dan masing-masing hanya mendapat sebidang sangat kecil. Lahan milik pribadi yang luas tapi terbagi-bagi dalam bidang kecil membuat unit usaha pertanian dijalankan dalam skala kecil yang menyebabkan biaya produksi dan manajemen tinggi dan yang paling penting hal itu menyebabkan ketimpangan input manusia-lahan. Penguasaan luasan tanah yang berbeda memberi peluang yang bebeda bagi petani. Bagi yang memiliki lahan luas mereka dapat mengkombinasi dan menanam tanaman pokok dan tanaman komersial secara bergantian. Selain itu, juga memungkinkan mereka membatasi tanaman 
untuk mencegah penurunan kualitas tanah. Luasan tanah pertanian tidak hanya berharga bagi petani. Bagi responden pedagang, makin besar volume produk, makin besar pula peluang untuk mengembangkan skala bisnis. Meningkatnya suatu sektor ekonomi akan menggandakan sektor lain. Makin besar kegiatan ekonomi suatu wilayah, makin banyak peluang pekerjaaannya, dan cenderung makin intensif pula perdagangannya.

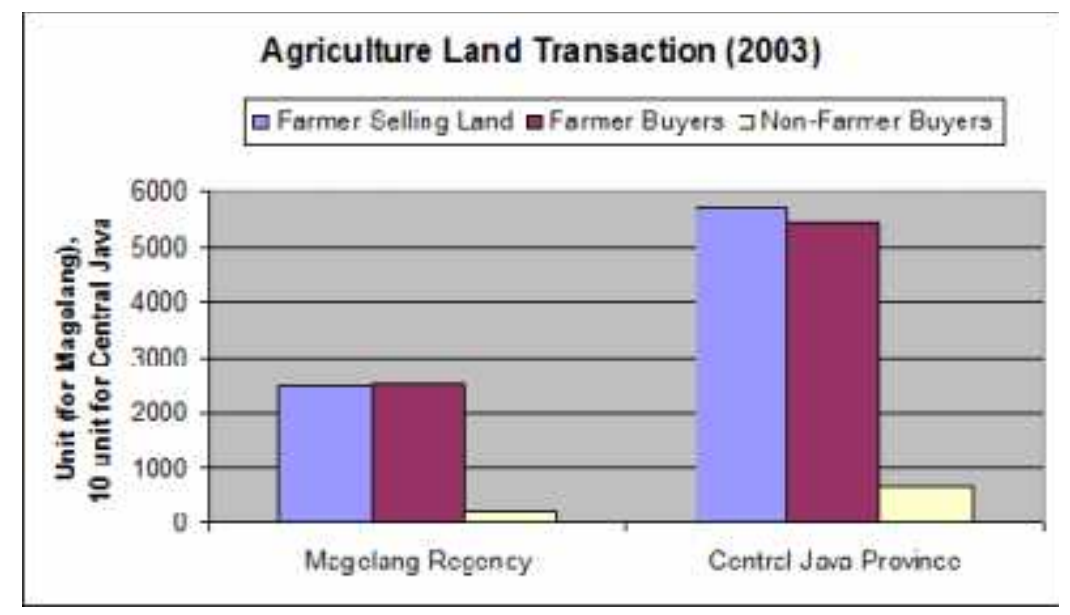

Gambar 3 Pola Transaksi Tanah Pertanian (BPS Jawa Tengah, 2004)

Memiliki lahan yang luas sangat didambakan petani di wilayah ini. Para petani juga tidak memandang tanah sebagai aset yang sebaiknya tidak pernah dijual. Terutama responden petani di pedesaan, jika tidak terpaksa petani sangat tidak tertarik untuk menjual tanahnya. Jika ada jual beli, pada umumnya terjadi antar petani. Di Magelang khususnya, jumlah petani yang menjual tanahnya sama dengan jumlah petani yang membeli tanah sebagaimana terindikasi dari grafik pada gambar 3.

Penjualan tanah oleh petani hanya dilakukan dalam keadaan yang sangat terpaksa, seperti pernyataan responden berikut:

"Jangan, jangan sampai saya menjual (tanah), kecuali jika saya bisa beli lahan yang lebih luas dan lebih baik dari hasil penjualan itu. Misalnya saya jual tanah ke pabrik dengan harga tinggi dan ada jaminan saya bisa mendapatkan tanah lain dengan uang itu, seperti beberapa orang di sini. Saya yakin leluhur tidak akan marah bila saya menjual tanah warisan untuk membeli tanah lain yang lebih luas. Nah, kalau jual tanah untuk spekulasi atau malah foya-foya, saya takut dosa dan dapat nasib buruk nantinya. Hidup tidak bisa diduga. Kadang ada keluarga yang tertimpa kemalangan misalnya sakit parah; kadang ada anak muda yang terpaksa pindah ke tempat lain demi pekerjaan yang lebih baik. Dalam kasus itu bisa jadi mereka jual tanah warisan. Siapa tahu, yang penting nabung saja kalau punya uang dan pasang telinga siapa tahu ada tanah dijual." (SF, 30, petani pemilik tanah di Kecamatan Tegalrejo, Magelang)

\section{3. Fluktuasi Penguasan Tanah oleh Petani}

Perkembangan industri telah menjadi pemicu transformasi ekonomi yang mengubah struktur ketenagakerjaan wilayah penelitian. Tumbuhnya sektor industri memicu terjadi migrasi tenaga kerja dari sektor pertanian. Hal inilah yang menjadi pemicu perubahan rasio penguasaan tanah oleh pentani. Contoh transformasi semacam ini terjadi di Kecamatan Tempuran dan Borobudur yang letaknya berdekatan. Tempuran adalah lokasi sebagian besar pembangunan industri terjadi, sementara Borobudur merupakan salah satu pemasok tenaga kerja industri. 


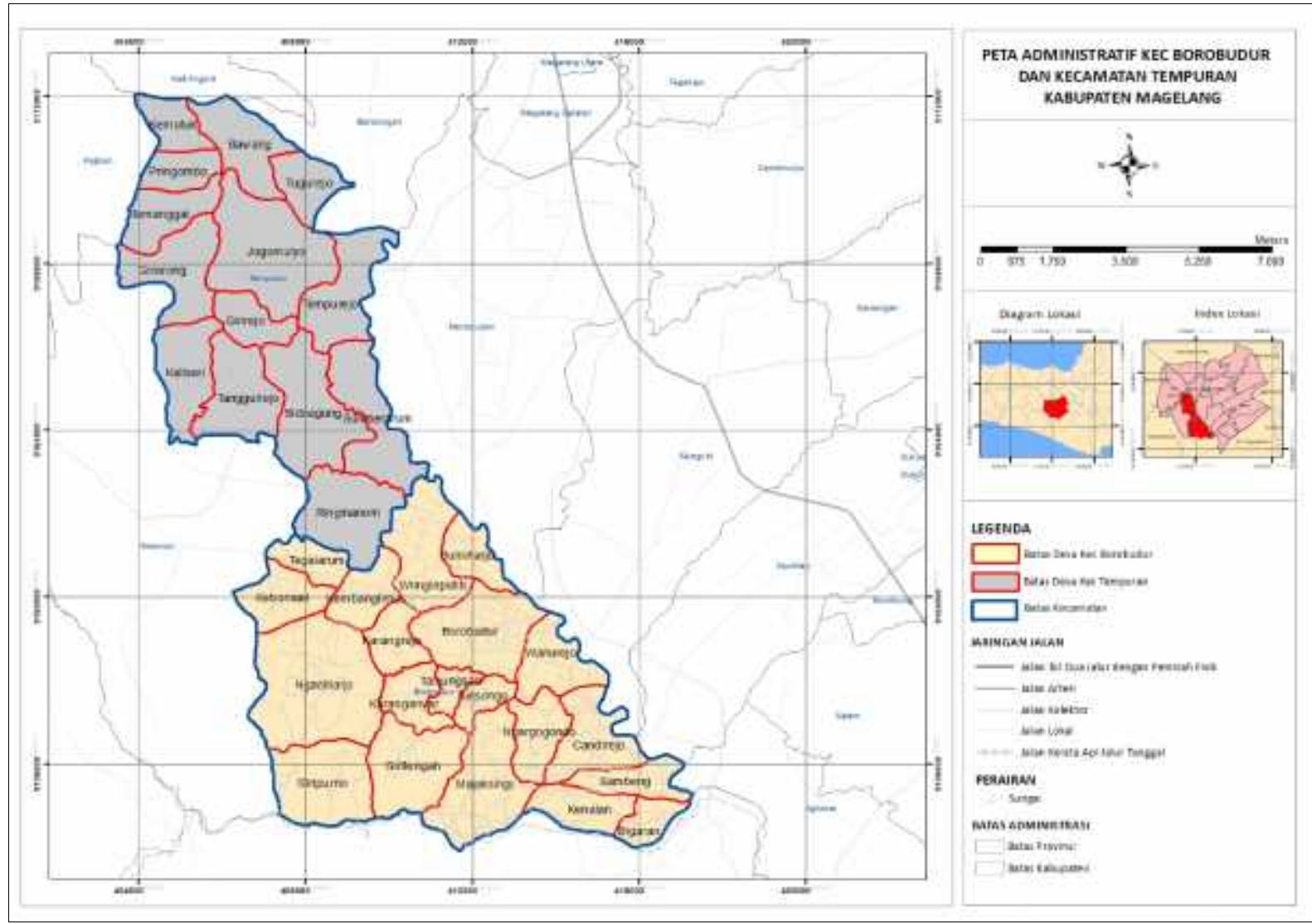

Gambar 4 Peta Borobudur danTempuran (Hasil Analisis, 2018)

Di wilayah pertanian pada 2 kecamatan ini, pembangunan industri telah memberi manfaat paling tidak untuk dua kelompok. Pertama, individu-individu yang memiliki kemampuan yang dibutuhkan industri, misalnya sehat, berpendidikan, atau memiliki keterampilan tertentu. Pembangunan industri membuka lapangan kerja untuk individu-individu dalam kelompok ini. Yang kedua adalah kelompok tani setempat. Mereka tidak memiliki kemampuan yang dibutuhkan industri atau tidak tertarik bekerja di bidang industri. Namun, perpindahan tenaga kerja pertanian ke sektor industri memberi mereka peluang untuk meluaskan usaha karena tanah yang tersedia untuk tiap individu jadi lebih luas. Perubahan penguasan tanah akibat dari industrialiasai ditunjukkan oleh gambar 5 yang menunjukkan perbandingan tanah-rumah tangga petani antara Tempuran dan Borobudur.

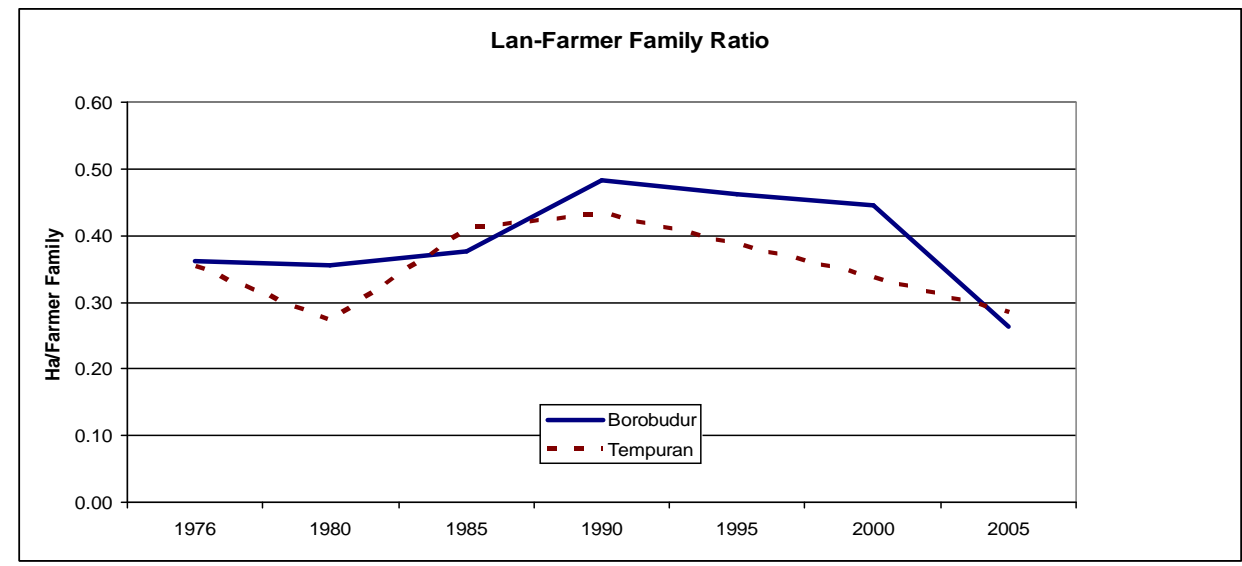

Gambar 5 Rasio Tanah-Petani di Kecamatan Borobudur dan Tempuran (disarikan dari Kabupaten Magelang dalam Angka, BPS, 1975-2005) 
Perubahan rasio lahan per petani terjadi karena perubahan mata pencaharian penduduk. Fluktuasi perkembangan industri di Kabupaten Magelang diikuti dengan fluktuasi komposisi tenaga kerja. Hal ini merupakan salah satu indikator terjadinya transformasi struktural ekonomi di wilayah. Data statistik pada gambar 6 memberi bukti bahwa pembangunan industri membuka peluang kerja dan menyerap tenaga kerja dari sektor pertanian.

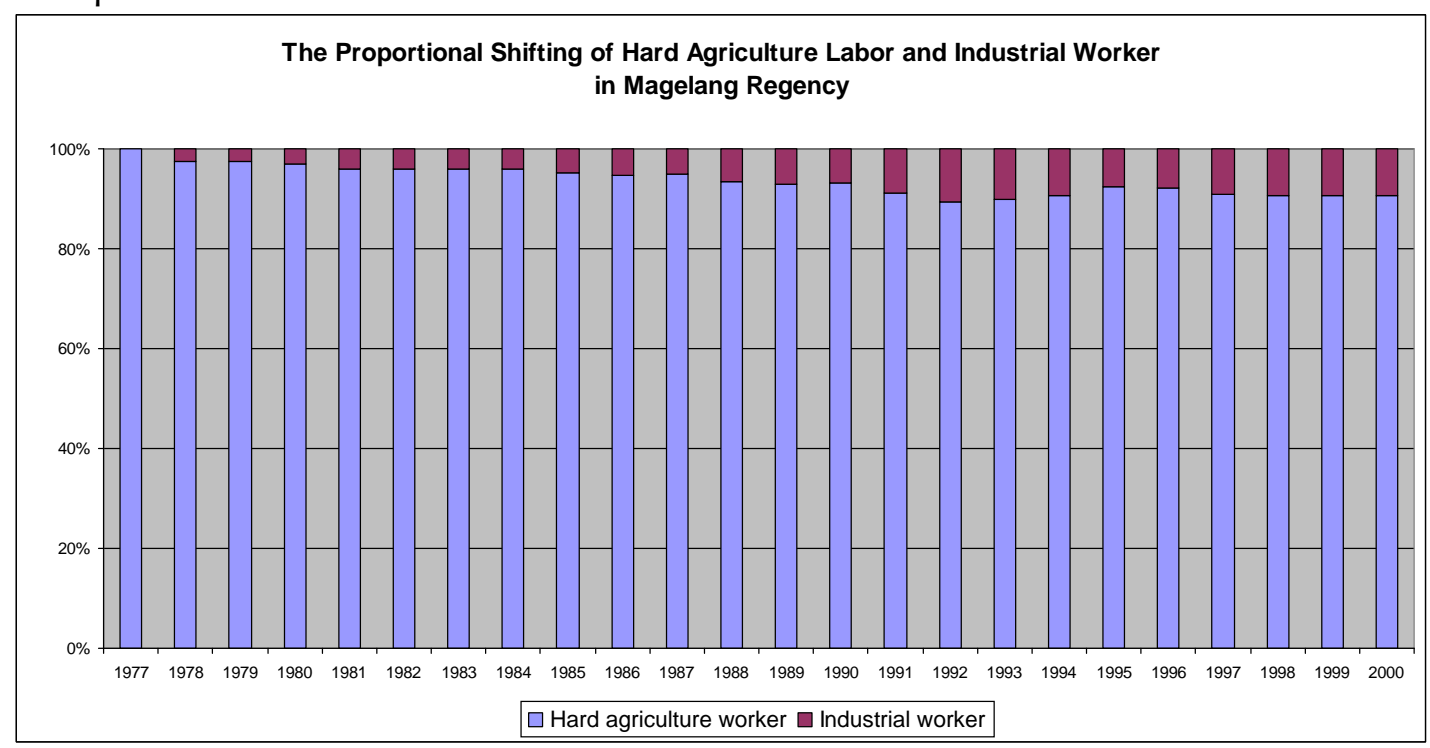

Gambar 6 Pergeseran Tenaga Kerja Pertanian Tanpa Keterampilan dan Pekerja Industri di Kabupaten Magelang (disarikan dari Kabupaten Magelang dalam angka, 1975-2005)

Data serial ini menunjukan bahwa proporsi pekerja buruh menurun mulai tahun 1978 hingga 1992, stabil dari 1992 hingga 1994 dan naik lagi hingga 1996, kemudian stabil lagi hingga sekitar tahun 2007. Data ini memberi indikasi bahwa tenaga kerja yang masuk ke sektor industri adalah tenaga kerja yang awalnya bekerja di sektor pertanian sebagai buruh. Mereka nyaris tidak memiliki atau tak punya lahan sama sekali. Mereka berpartisipasi mengolah lahan yang tidak cukup luas. Pada dasarnya pemilik lahan pun tak butuh banyak waktu untuk mengurus. Dilihat dari skala ekonomi, hal ini menunjukkan adanya ketidak-efisienan pengolahan lahan. Fenomena ini juga terjadi sebagai wujud solidaritas antara petani pemilik dan pengolah lahan. Pemilik lahan memberi kesempatan bagi petani pengolah yang tidak memiliki lahan untuk mendapatkan penghasilan.

\section{4. Perubahan Kapabilitas Masyarakat Akibat Fluktualisasi Industrialisasi}

Perubahan akses terhadap tanah merupakan aset penting terutama bagi petani, untuk meningkatkan kapabilitas mereka. Hal ini dikarenakan menentukan peluang peningkatan skala usaha yang dapat mereka bangun. Pada kasus penelitian ini, perubahan akses penguasaan tanah pertanian secara individu merupakan bagian dari indikator transformasi struktural ekonomi sebagaimana diungkap oleh Kaldor (1966) yang terkait dengan perubahan komposisi pekerjaan penduduk. Proses ini dipengaruhi oleh fluktuasi industrialisasi yang terjadi di wilayah ini. Masyarakat di wilayah Borobudur mendapat keuntungan dari perkembangan industri di Tempuran karena sebagian tenaga kerjanya terserap di sektor industri dan mengurangi kepadatan tenaga kerja pada sektor pertanian. Misalnya, bagi seorang pelopor budi daya pepaya, SW (50) yang mengatakan bahwa budi daya pepaya yang dia lakukan merupakan sebuah ketidaksengajaan. la mengatakan bahwa kebanyakan tanah di Borobudur tidak begitu subur, terutama untuk bertanam padi, hingga keluarganya mulai menanam pepaya di tanah gersang mereka dan dengan sukses memasarkannya ke Semarang dan Yogyakarta. Seiring naiknya permintaan pepaya ini, banyak petani kemudian tertarik mengikuti langkahnya. Berhektar-hektar tanah diubah menjadi kebun pepaya. SW sendiri membutuhkan lebih banyak lahan untuk memperluas kebunnya karena pepaya membutuhkan tanah yang lebih luas dibandingkan komoditas lain seperti padi. Meskipun demikian, investasi pepaya tidak 
begitu besar dan perawatannya juga tidak begitu sulit. Untuk mendukung skala usaha ekonomi petani secara optimal, diperlukan peningkatan rasio tanah-petani. Dalam hal ini, pembangunan industri di Tempuran justru membuka peluang besar. Banyak pekerja pabrik di Tempuran berasal dari Borobudur. Perubahan ini membuat tenaga kerja pertanian di Borobudur berkurang dan meningkatkan rasio tanahpetani di wilayah ini. Petani tersisa merasakan untung karena memperoleh peluang untuk menyewa lahan dari orang-orang yang pergi bekerja di pabrik. Produksi pepaya di wilayah ini kemudian mengalami pertumbuhan pesat hingga sekitar 1997. Pemasaran pepaya produksi wilayah ini dapat meluas hingga Yogyakarta dan Semarang.

De-industrialisasi berdampak pada penurunan usaha para petani. Krisis ekonomi dan kelesuan industri yang mengikutinya berbuntut pada kembalinya penurunan rasio tanah-petani. Sejumlah pekerja pabrik kemudian kembali bertani. Namun, produksi pepaya juga turun di waktu yang sama. Mengapa hal ini terjadi? Hal ini erat kaitannya dengan upaya bertahan (hidup) manusia (livelihood strategy). (Lihat gambar 7 dan 8). Di Borobudur, produksi padi meningkat (kembali) sejak tahun 1998. Penanaman padi dilakukan di lahan yang masih tersedia dan tidak dialihfungsikan menjadi lahan industri seperti di Tempuran (lihat gambar 7 dan 8). Untuk melengkapi penjelasan pengaruh industrialisasi terhadap penguasan tanah dan kapabilitas, observasi difokuskan pada tingkat dusun, yaitu, Dusun Turus, Kecamatan Tempuran, sebagai lokasi pembangunan industri. Turus terletak kurang lebih $1 \mathrm{~km}$ dari jalan raya provinsi. Sebelum adanya pembangunan industri pada awal 1980an, Turus hanyalah dusun kecil yang didominasi oleh petani kecil dengan tanah gersang. Kemunculan industri mengubah profil dusun tersebut. Harga tanah, yang awalnya tak pernah terpikir oleh penduduk desa, menjadi topik perbincangan sehari-hari. Saat industri tiba, mereka bersedia membeli tanah seharga paling tidak $\mathrm{Rp} 25.000$ per $\mathrm{m}^{2}$. Ada beberapa orang yang tanpa ragu menjual tanah mereka kepada industri. Namun, terdapat pula negosiasi-negosiasi yang digagas terutama oleh penduduk muda dan para pemimpin informal. Mereka menuntut agar penduduk lokal diprioritaskan menjadi pekerja. Hasilnya, banyak penduduk lokal terserap dalam industri tersebut, misalnya industri payung, furnitur, tekstil, spare-part mobil, karoseri mobil, dan produk-produk dari semen.

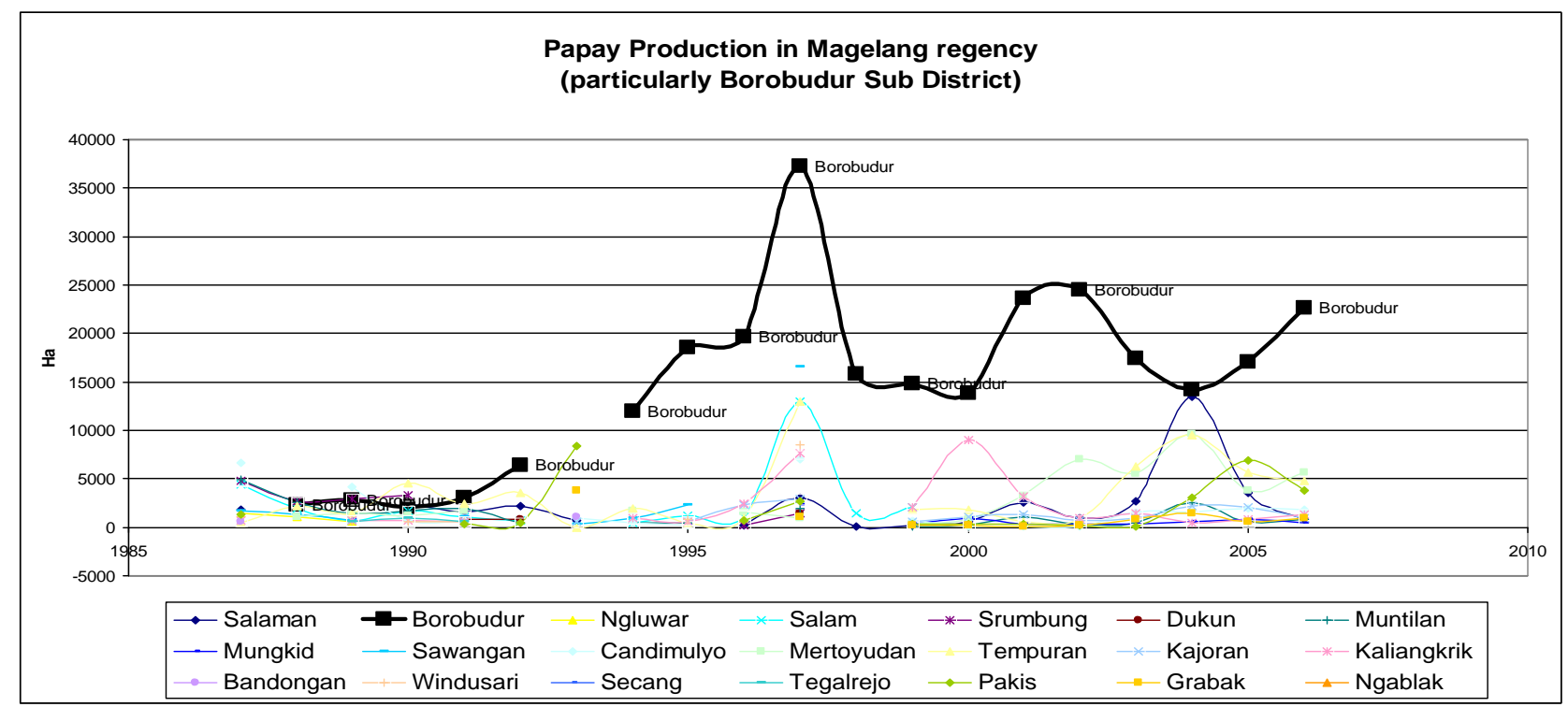

Gambar 7 Produksi Pepaya Magelang (disarikan dari Kabupaten Magelang dalam Angka, BPS, 1975-2005) 


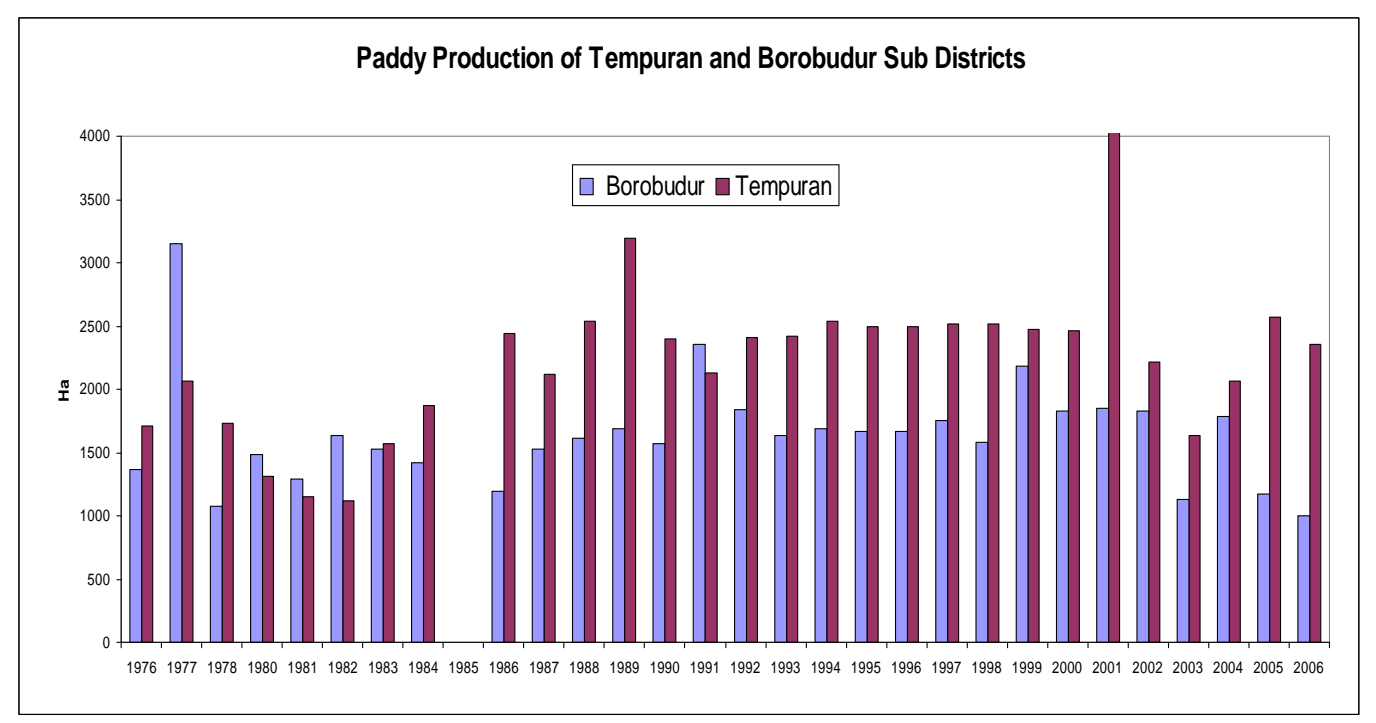

Gambar 8 Produksi Padi di Borobudur dan Tempuran

(disarikan dari Kabupaten Magelang dalam Angka, BPS, 1975-2005)

Dari 1980-an hingga pertengahan 1990-an, Dusun Turus, Kecamatan Tempuran, dan sekitarnya menikmati GDP tertinggi di Kabupaten Magelang. Kejatuhan industri akibat krisis mengejutkan penduduk Turus dan desa-desa sekitar, yang mayoritas adalah pekerja pabrik. Sejak saat itu, angka pengangguran meroket (kurang lebih 20\%). Mereka yang pernah bekerja sebagai buruh pabrik tak dapat kembali bertani karena lahan pertanian telah beralih tangan dan berubah fungsi. Mantan pekerja karoseri mobil pada umumnya bermigrasi ke kota besar bahkan ke luar pulau. Generasi muda merupakan kelompok paling menderita. Mereka sudah terlanjur tersisih dari kegiatan pertanian karena nyaris seluruh sektor pertanian sudah punah dari desa. Mereka tidak terlatih bertani seperti orangtua mereka, sementara keahlian lain tak ada. Situasi ini makin buruk karena mereka nyaris tidak mewarisi tanah dari orangtua mereka.

Dalam kasus Borobudur, industrialisasi di kecamatan tetangga (Tempuran) yang merepresentasikan peningkatan aset institusi ekonomi dalam bentuk keragaman sektor ekonomi dan peluang kerja, berdampak pada peningkatan kepemilikan tanah pribadi. Dalam fase berikutnya, kepemilikan tanah pribadi yang lebih banyak ini mengubah komposisi produk pertanian yaitu munculnya sub sektor ekonomi dalam bidang budi daya pepaya. Semua perubahan ini memunculkan nilai ekspor-impor, yang langsung meningkatkan kesejahteraan. Hal ini dapat diartikan bahwa industrialisasi telah membuka kesempatan bagi petani di Borobudur untuk memperluas sekaligus memperbanyak ragam usaha mereka.

Industrialisasi memunculkan aset baru. Akan tetapi, kebalikannya, industrialisasi yang tidak berkelanjutan atau de-industrialisasi yang disebabkan bukan karena transformasi menuju dominasi sektor tersier, menimbulkan efek buruk bagi masyarakat. Beberapa orang yang berada di wilayah perindustrian mengalami perubahan aset yang cukup drastis, ada yang berkurang, ada pula yang meningkat. Selama fase peningkatan, industrialisasi pada umumnya meningkatkan peluang kerja, namun pada saat yang sama mengurangi aset tanah. Saat industri mengalami kebangkrutan, peluang kerja akan berkurang, namun beberapa orang tetap kehilangan tanah. Industrialisasi juga menyebarkan keterampilan-keterampilan untuk membuka usaha kecil bagi beberapa kelompok orang. Penyebaran keterampilan melalui industrialisasi ini akan dibahas dalam bab berikutnya.

Beruntungnya, sebagaimana diungkap oleh Browett (1985), meskipun berhentinya sebagian industri telah menjatuhkan perekonomian masyarakat dalam waktu dekat, namun jangka agak panjang industri telah meninggalkan keterampilan yang menjadi modal bagi masyarakat lokal untuk bangkit kembali. Berdasarkan pengamatan kualitatif, mantan pekerja khususnya pabrik makanan dan karoseri mobil mendapatkan keuntungan keterampilan yang dapat diterapkan dalam usaha kecil, misalnya bengkel cat mobil maupun usaha pengolahan makanan skala rumah tangga. Di sepanjang jalan kabupaten, mudah 
dijumpai bengkel-bengkel kecil yang menyediakan jasa pengecatan, interior mobil, dsb. Pada kasus 2 kecamatan di Magelang, turunnya kegiatan pada sektor industri besar, jika ada transfer ketrampilan, telah mampu menjadi pendorong transformasi ekonomi yang berupa industrialisasi lokal. Gambar 9 menunjukkan kenaikan tajam pekerja di industri kecil/rumah tangga setelah era turunnya industri besar. Dalam pengamatan lapangan, ada indikasi sebagian mantan pekerja industri besar dan menengah menciptakan lapangan kerja di sektor industri kecil dan rumah tangga.

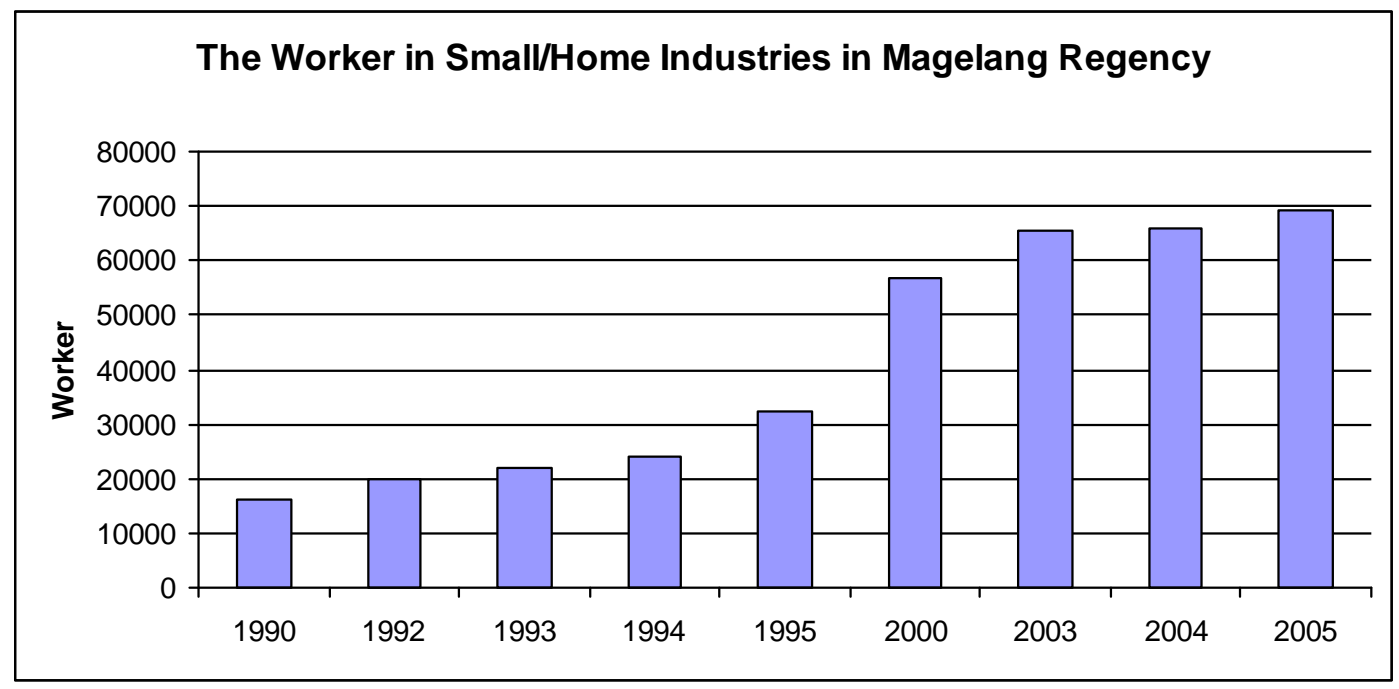

Gambar 9 Pertumbuhan Pekerja pada Industri Kecil/Rumah Tangga di Kabupaten Magelang (disarikan dari Kabupaten Magelang dalam Angka, BPS, 1975-2005)

Pertanyaannya, mengapa mereka baru membuka industri kecil setelah industri runtuh? Mengapa tidak sebelumnya? Apakah mereka tidak menyadari bahwa tanah semakin mengecil dari luasan sebelumnya dan mereka tidak bisa menggunakan aset tenaga kerja mereka secara optimal? Hal ini terjadi karena mereka (mantan pekerja industri besar) baru memperoleh keterampilan setelah bekerja di pabrik. Keragaman keterampilan adalah salah satu dampak positif pembangunan industri besar dan menenagah di wilayah ini sebelum terjadi de-industrialisasi. Proses perkembangan industri kecil rumah tangga ini dapat dikatakan sebagai gejala re-industrialisasi.

\section{KESIMPULAN}

Dengan fakta-fakta yang telah dibahas, industrialisasi, meliputi melalui fase perkembangan, deindustrialiasasi dan re-industrialisasi telah sangat mempengaruhi perkembangan kapabilitas masyarakat. Pada tahap awal, perkembangan industrialiasasi menjadi aset masyarakat berupa menigkatknya akses pekerjaan baru pada sektor industri, yang berakibat pada peluang peningkatan skala usaha pertanian pada rumah tangga petani. Yang kedua, peningkatan angka parisipasi kerja dan jam kerja masyarakat telah meningkatkan pendapatan dan akhirnya konsumsi rumah tangga termasuk pada sektor pertanian. Yang ketiga, meskipun sempat memberi shock pada saat terjadi de-industriaslisasi, peningkatan keterampilan oleh fase sebelumnya telah memberi modal bagi masyarakat lokal untuk ber-re-industrialisasi yang akhirnya menumbuhkan sistem ekonomi baru yang berbasis industri rumah tangga. Hal yang paling negatif dari fenomena fluktuasi industri adalah kurang terantisipasinya shock dari masyarakat terkait dengan harga lahan. Peningkatan harga lahan yang tinggi di awal perkembangan telah memancing masyarakat, terutama generasi mudanya untuk melepas lahan mereka karena sadah merasa tidak akan tertarik kembali pada sektor pertanian dan berharap dapat selalu bekerja pada sektor industri. Saat terjadi deindustrialisasi, kelompok inilah yang paling jatuh kapabilitasnya. Berdasar pada temuan-temuan dalam penelitian ini, rekomendasi penting bagi proses perencanaan wilayah adalah memberi perhatian lebih pada 
proses mengarahkan tata guna lahan wilayah. Perencana perlu mengembangkan kerangka komprehensif yang adaptif yang dapat menjadi pedoman alokasi lahan masyarakat, izin penggunaan tanah, manajemen tanah untuk menfasilitas sewa-menyewa lahan pertanian

\section{REFERENSI}

Álvarez, J., Bilancini, E., D'Alessandro, S., Porcile, G., (2011) Agricultural institutions, industrialization and growth: The case of New Zealand and Uruguay in 1870-1940. Explorations in Economic History 48 (2011) 151-168. doi:10.1016/j.eeh.2010.05.004

Amstrong, H. W. \& Taylor, J. (2000) Regional Economics and Policy, Blackwell: Oxford

Arsyad, Lincolin (2004). Ekonomi Pembangunan. Edisi Ke-empat. STIE YKPN

Bertrand, Alvin L. and Harold W. Osborne. (1959) "The Impact of Industrialization on a Rural Community." Journal of Farm Economics, Vol. XLI, No. 5. December, 1959

Bloch, A. (2000). Technologies transfer to a developing country: the road to industrialization. Preprints of IFAC Conference on Technology Transfer

Browett, J. (1985). The Newly Industrializing Countries and Radical Theories of Development World Development. Elsevier

BPS Jawa Tengah (2004). Laporan Sensus Pertanian 2003, Jawa Tengah Angka 2004. Semarang, Jawa Tengah

BPS Kabupaten Magelang (1975 - 2005). Kabupaten Magelang dalam Angka 1975 - 2005. Magelang

Dasgupta, S and Singh, A. (2006). Working Paper: Manufacturing, Services and Premature Deindustrialization in Developing Countries. A Kaldorian Analysis. UNU World Institute for Development Economics Research (UNU-WIDER) https://www.wider.unu.edu/sites/default/files/rp2006-49.pdf

Friedmann, J. (1996) 'The Core Curriculum in Planning Revisited', Journal of Planning Education and Research, 15, 89

Kim, J. Hong. (2011) 'Linking Land Use Planning and Regulation to Economic Development: A Literature Review', Journal of Planning Literature February, 26(1), 35-47

Kaldor, N. (1966). Marginal Productivity and the Macro-Economic Theories of Distribution: Comment on Samuelson and Modigliani. The Review of Economic Studies, Vol. 33, No. 4 (Oct., 1966), pp. 309-319

Kitson, M and Michie, J. (1997) Does Manufacturing Matter?, International Journal of the Economics of BusinessVol4, No.1:71-96

Mirana (2008). Industrialisasi di Indonesia: dalam Jebakan Mekanisme Pasar dan Desentralisasi. Pidato Pengukuhan Guru Besar dalam Bidang Ilmu Ekonomi UI, Jakarta

Pramono, R. W. D., \& Woltjer, J. (2011). Wellbeing and a Capability Approach in Planning Evaluation and Regional Development. Chapter In Evaluation for Participation and Sustainability in Planning Edited by Angela Hull, E.R. Alexander, Abdul Khakee, Johan Woltjer. Routledge

Putterman, L. (2013). Institutions, social capability, and economic growth. Economic systems, 2013Elsevier

Republik Indonesia. (1960). Undang - Undang No. 5 Tahun 1960 tentang Tentang Peraturan Dasar PokokPokok Agraria. LEMBARAN NEGARA 1960 - 104. Sekretaris Negara, Jakarta

Rowthorn, R. E. and Wells, J. R., (1987), De-Industrialisation and Foreign Trade, Cambridge, Cambridge University Press

Rowthorn, R., and Ramaswamy, Ramana (1997). Deindustrialization: Causes and Implications. IMF Working Paper

Sachs, Jeffrey D., Shatz, Howard J., Deardorff, Alan, and Hall, Robert E.. (1994) Brookings Papers on Economic Activity, Vol. 1994, No. 1. (1994), pp. 1-84. URL: http://links.jstor.org/sici?sici=00072303\%281994\%291994\%3A1\%3C1\%3ATAJIUM\%3E2.0.CO\%3B2-7

Sen, A. K. (2000) Development as Freedom, Oxford University Press 
Sigurdson (1977). Rural Industrialization in China. This Monograph on Rural Industrialization In China. Books.google.com

Škuflić, L \& Družić, M (2016) Deindustrialisation and productivity in the EU, Economic Research-Ekonomska Istraživanja, 29:1, 991-1002, DOI: 10.1080/1331677X.2016.1235505 